\title{
Application and outlook of topical hemostatic materials: a narrative review
}

\author{
Yuting Zhong', Huayu $\mathrm{Hu}^{2}$, Ningning Min ${ }^{2}$, Yufan $\mathrm{Wei}^{2}$, Xiangdong $\mathrm{Li}^{3}, \mathrm{Xiru} \mathrm{Li}^{4}$ \\ ${ }^{1}$ Department of General Surgery, Chinese PLA Hospital \& Chinese PLA Medical School, Beijing, China; ${ }^{2}$ School of Medicine, Nankai University, \\ Tianjin, China; ${ }^{3}$ State Key Laboratory of Agrobiotechnology, College of Biological Sciences, China Agricultural University, Beijing, China; \\ ${ }^{4}$ Department of General Surgery, Chinese People's Liberation Army General Hospital, Beijing, China \\ Contributions: (I) Conception and design: X Li, X Li; (II) Administrative support: X Li; (III) Provision of study materials or patients: X Li; (IV) \\ Collection and assembly of data: All authors; (V) Data analysis and interpretation: All authors; (VI) Manuscript writing: All authors; (VII) Final \\ approval of manuscript: All authors. \\ Correspondence to: Xiru Li. Department of General Surgery, Chinese People's Liberation Army General Hospital, Beijing 100853, China. \\ Email: 2468li@sina.com. Xiangdong Li. State Key Laboratory of Agrobiotechnology, College of Biological Sciences, China Agricultural University, \\ Beijing 100193, China. Email: xiangdongli68@126.com.
}

\begin{abstract}
Bleeding complications can cause significant morbidities and mortalities in both civilian and military conditions. The formation of stable blood clots or hemostasis is essential to prevent major blood loss and death from excessive bleeding. However, the body's self-coagulation process cannot accomplish timely hemostasis without the assistance of hemostatic agents under some conditions. In the past two decades, topical hemostatic materials and devices containing platelets, fibrin, and polysaccharides have been gradually developed and introduced to induce faster or more stable blood clot formation, updating or iterating traditional hemostatic materials. Despite the various forms and functions of topical hemostatic materials that have been developed for different clinical conditions, uncontrolled hemorrhage still causes over 30\% of trauma deaths across the world. Therefore, it is important to fabricate fast, efficient, safe, and ready-touse novel hemostatic materials. It is necessary to understand the coagulation process and the hemostatic mechanism of different materials to develop novel topical hemostatic agents, such as tissue adhesives and sealants from various natural and synthetic materials. This review discusses the structural features of topical hemostatic materials related to the stimulation of hemostasis, summarizes the commercially available products and their applications, and reviews the ongoing clinical trials and recent studies concerning the development of different hemostatic materials.
\end{abstract}

Keywords: Topical hemostatic materials; hemostatic mechanism; hemostatic products; outlook

Submitted Oct 28, 2020. Accepted for publication Jan 22, 2021.

doi: $10.21037 /$ atm-20-7160

View this article at: http://dx.doi.org/10.21037/atm-20-7160

\section{Introduction}

Trauma from both battlefield and civilian conditions is the leading cause of death worldwide $(1,2)$. Uncontrolled hemorrhage resulting from traumatic injury can cause various complications, such as hypothermia, coagulopathy, infection, acidosis, and multiple organ failure, significantly increasing health care costs, morbidities, and mortalities. Also, certain congenital or disease-associated conditions, as well as chemotherapy- and radiotherapy-related effects, can put certain groups of patients at high risk of bleeding. Therefore, effective hemostasis is potentially life-saving in the prehospital setting and is also highly significant in clinical treatments (3-5). Topical hemostatic materials applied locally to bleeding wounds currently play an important role in hemostasis during surgery. To develop efficient and novel topical hemostatic agents, such as tissue adhesives and sealants from various natural and synthetic 


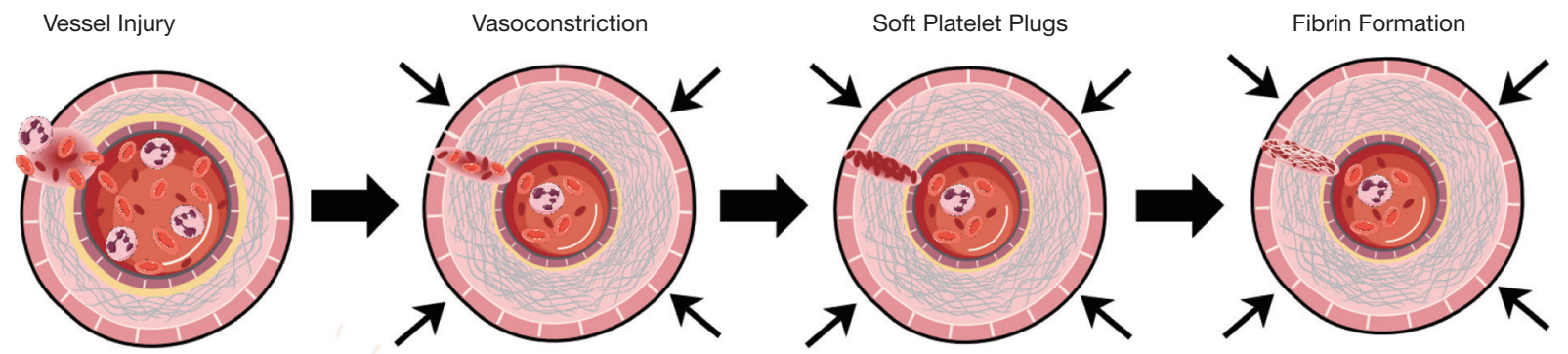

Figure 1 The comprehensive action of three mechanisms for effective hemostasis.

materials, substantial interdisciplinary research efforts are necessary to conduct robust studies focused on fabricating an ideal hemostatic dressing. These would include establishing and perfecting animal models of trauma, inventing effective hemostatic devices, and conducting clinical trials in multidisciplinary settings (6). The ideal hemostatic dressing possesses the following properties: the ability to stop bleeding within 2 minutes; adequate biodegradability and bio-absorbability; clinical safety; ease of use; and low cost (7).

This review discusses the structural features of topical hemostatic materials used to stimulate hemostasis, summarizes the currently available commercial products and their applications, and provides a review of recent clinical trials.

We present the following article in accordance with the Narrative Review reporting checklist (available at http:// dx.doi.org/10.21037/atm-20-7160).

\section{An overview of blood coagulation}

Blood coagulation is a physiological process with a complex mechanism involving the coordination of various blood components, such as coagulation factors, cells, etc. Overall, effective hemostasis works via three comprehensive mechanisms of action: vasoconstriction, the formation of platelet plugs, and blood clotting (Figure 1).

When the surface of blood vessels is damaged, vasoconstriction is triggered by the vascular smooth muscle contracting, leading to blood vessel constriction, slowing of blood flow, and reduction of blood loss. Simultaneously, platelets activate, adhere, and aggregate at the injured site forming soft platelet plugs. This process is known as primary hemostasis, which only provides a short-term effect. Secondary hemostasis occurs simultaneously: The soft platelet plugs consolidate to form a permanent, stable plug involving the coagulation system and various blood components. The coagulation cascade includes two basic pathways: the intrinsic pathway (contact activation) and the extrinsic pathway (tissue factors). The extrinsic pathway is activated by tissue factors released from the damaged vessels, while the intrinsic pathway is activated by factor XII released from the contact of blood with a foreign surface. Ultimately, both pathways lead to the common pathwaythe activation of factor $\mathrm{X}$, one of the prothrombinase complex components, which in turn converts prothrombin to thrombin. The activated thrombin converts the soluble fibrinogen into the insoluble fibrin, a three-dimensional fibrous network, which subsequently forms a stable plug $(8,9)$, as depicted in Figure 2.

\section{Classification of hemostatic materials}

\section{Classification by material sources}

Hemostatic materials can be grouped into four categories based on the material source: inorganic hemostatic material, polysaccharide hemostatic material, biological hemostatic material, and synthetic hemostatic material, as depicted in Table 1. Hemostats based on inorganic materials are derived from natural minerals. They have advantages such as abundant source, low cost, porous structure, super absorbent capacity, and nil risk of bloodborne disease, but most of them are not bioabsorbable and need to be removed after application. Polysaccharide-based hemostatic materials, composed of natural carbohydrates, are attractive to researchers because of their bioabsorbable features and low cost. Biologically derived hemostatic materials have an excellent hemostatic performance by directly increasing clotting substances, but the high cost and risk of immune reactions and viral infections hamper the wider use of these materials. Synthetic hemostatic materials can be industrially fabricated and formulated with other adjuncts to improve their biocompatibility. Although the raw materials used to synthesize hemostatic materials 


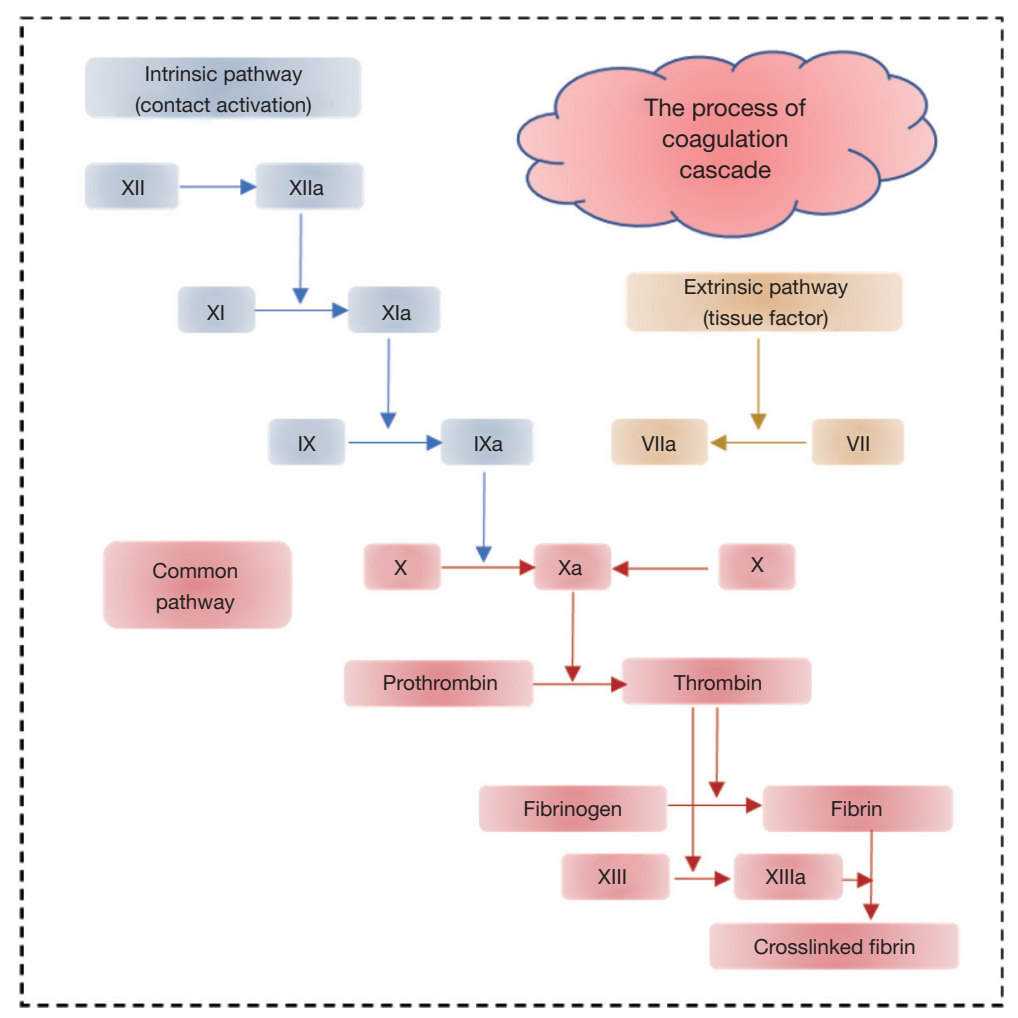

Figure 2 Schematic of the brief mechanism of blood vessel hemostasis.

Table 1 Main components and mechanism of action of commercial hemostatic products

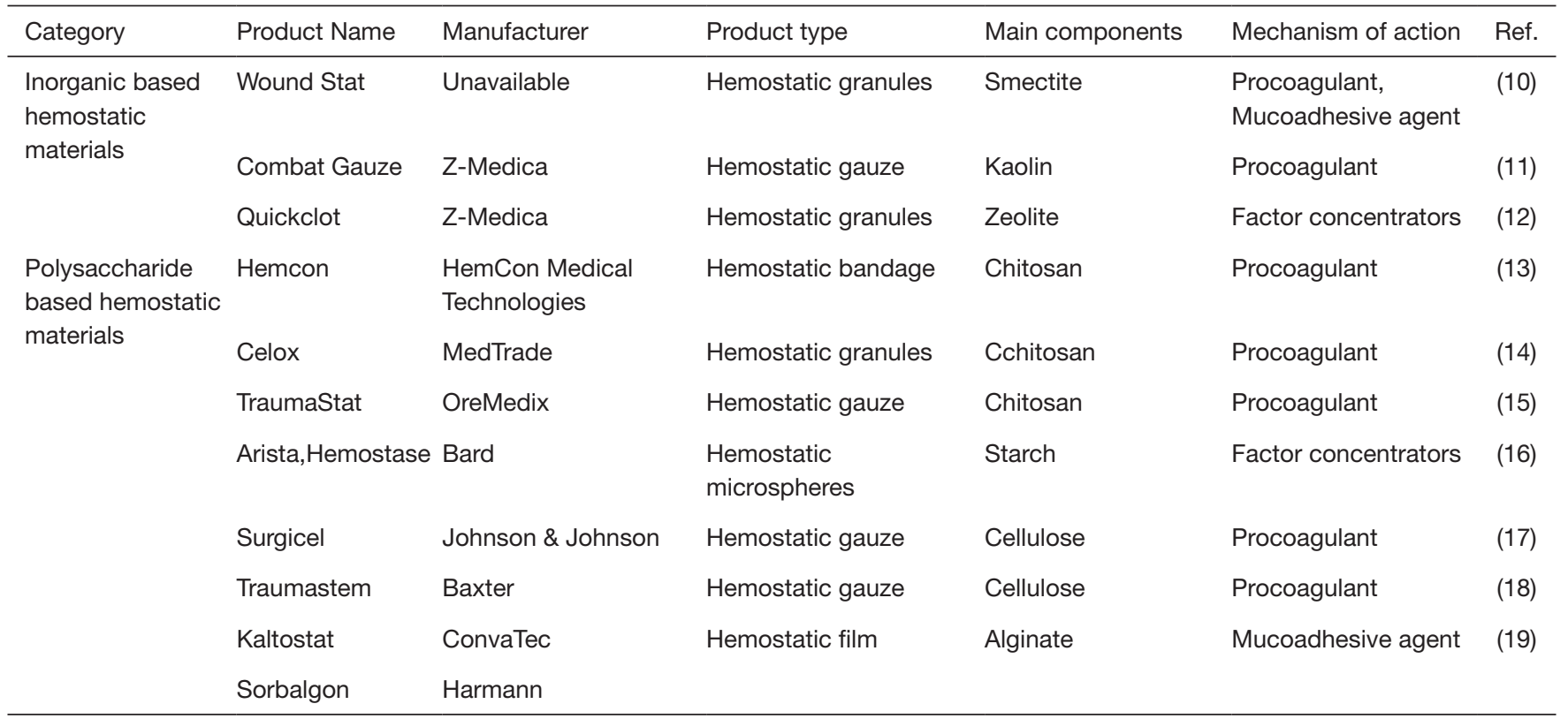

Table 1 (continued) 
Table 1 (continued)

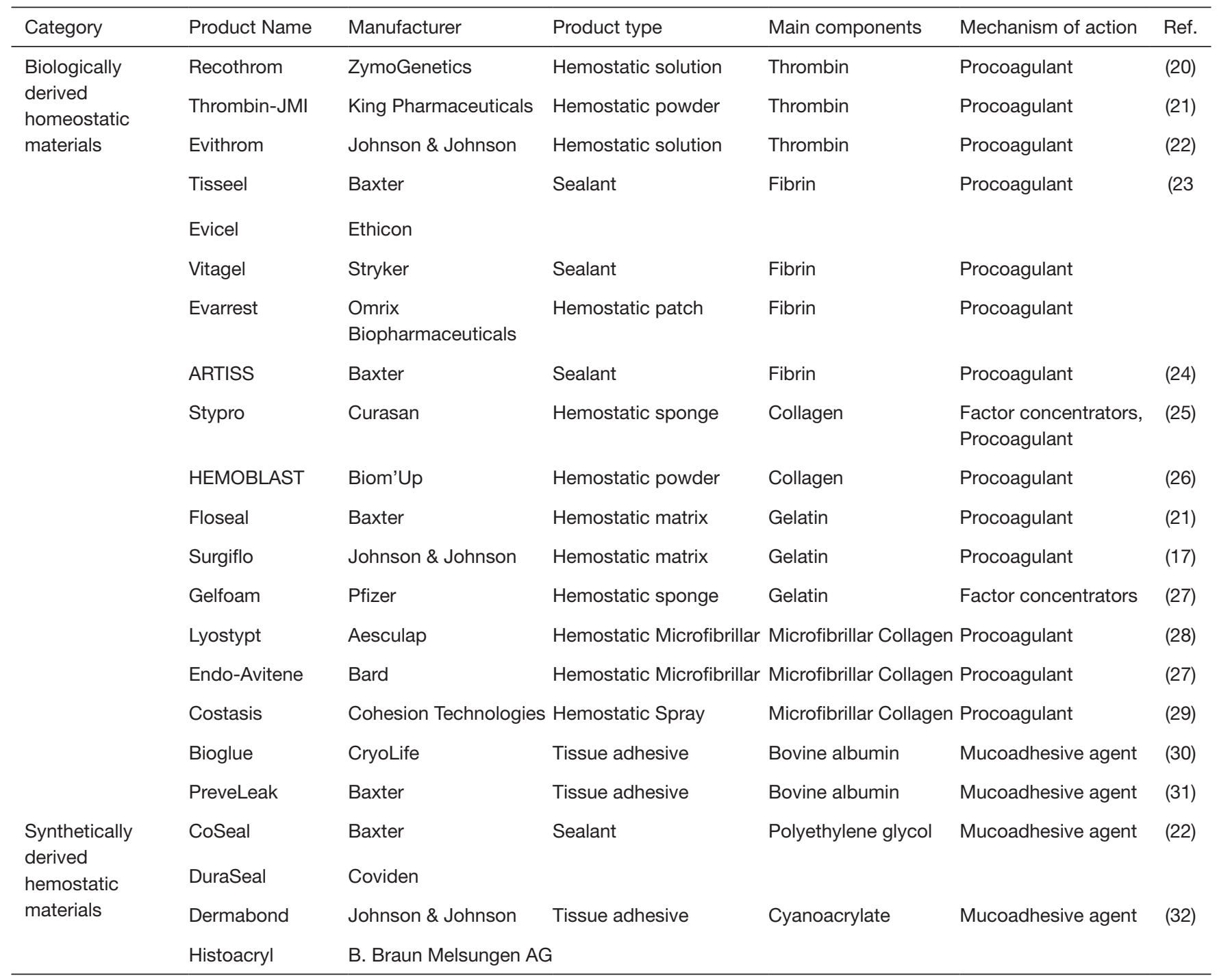

are relatively cheap, choosing different formulations to develop synthetic hemostatic materials with efficient hemostatic properties remains the research focus of many scholars worldwide. Furthermore, potential problems, such as cytotoxicity and non-biodegradability, should be noted. Further clinical investigations are required to confirm synthetic hemostatic materials' effectiveness and safety before applying for FDA approval.

\section{Classification by mechanism of action}

Hemostatic materials are grouped into three categories based on their mechanism of action: factor concentrators, procoagulants, and mucoadhesive agents (Figure 3). Factor concentrators work by absorbing water from the blood and concentrating the blood components at the injury site. Procoagulants take action through supplementing coagulation factors and activating the blood coagulation cascade. Mucoadhesive agents provide a physical barrier to blood flow by cross-linking blood components (33). Table 1 summarizes the classification of hemostatic materials based on their main components.

\section{Inorganic-based hemostatic materials}

A variety of inorganic materials have been developed that 


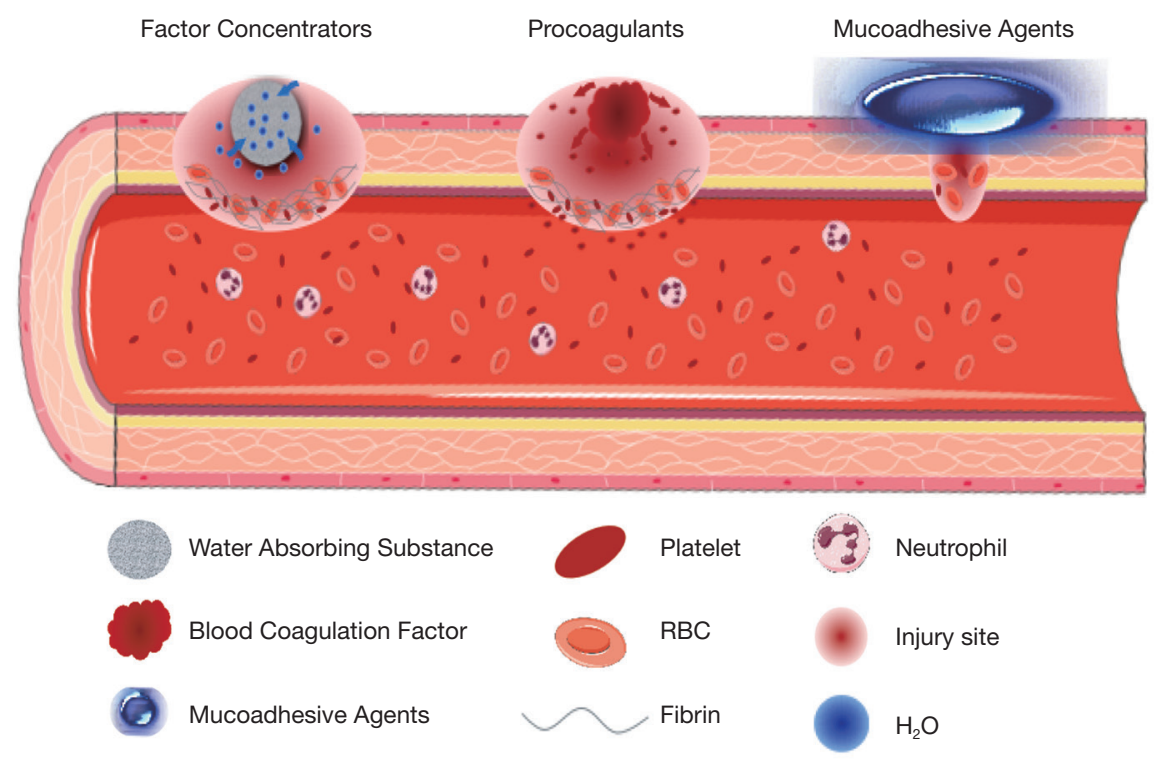

Figure 3 Classification of hemostatic materials by their mechanism of action.

can accelerate blood coagulation, including zeolites and clays. Hemostats based on inorganic materials are derived from natural minerals. They have advantages such as source abundance, low cost, porous structure, super absorbent capacity, and nil risk of bloodborne disease, but most of them are not bioabsorbable and need to be removed after use.

\section{Zeolite}

Zeolites, a class of crystalline microporous minerals, are constructed of corner-sharing tetrahedral units of $\left[\mathrm{SiO}_{4}\right]^{4-}$ and $\left[\mathrm{AlO}_{4}\right]^{5-}$. Such framework structures have properties of a large surface area and high porosity and stimulate the hemostatic effect by absorbing water from the blood and concentrating blood cells, platelets, and clotting factors at the injury site, thereby promoting coagulation (34). QuikClot, the first-generation commercial zeolite-based hemostat, is a granular preparation that is directly poured on the bleeding site. QuikClot rapidly absorbs water and achieves hemostasis and generates an exothermic reaction, causing an undesirable side effect for application in vivo. To avoid this side effect, the second-generation QuikClot ACS (Advanced Clotting Sponge), has been produced and is reported to be more effective than QuikClot, especially when applied to irregular injury sites without being freely distributed into the wound. This product is also easier to remove and produces less exothermic reaction than

\section{QuikClot (12).}

Natural zeolites have some extra advantages over their synthetic analogs, including low cost, an easy manufacturing process, and high biocompatibility. In a groin injury lethal rabbit model, the hemostatic efficiency and wound healing properties of natural zeolite granules were evaluated. Compared with Quikclot, natural zeolite granules achieved less mortality ( $21 \%$ vs. $52.6 \%)$ and facilitated wound healing (35). To increase survival in the prehospital setting, a flexible mesoporous zeolite-cotton hybrid hemostat was synthesized with various advantages, such as meso-/ micro-porosity, quick blood coagulation, and stability. The combination of cotton and zeolites can achieve rapid hemostasis and save lives in emergencies, especially in the absence of sufficient first aid measures (36).

\section{Clays}

Clay minerals, a class of hydrous aluminum silicates, consist of tetrahedral silicate sheets and octahedral aluminate sheets, including 1:1 clay and 2:1 clay based on the ratio of tetrahedral to octahedral sheets. Smectite is one example of a 2:1 clay mineral containing an octahedral sheet between two tetrahedral sheets, and kaolin is one example of a 1:1 clay mineral consisting of one silica tetrahedral layer to one aluminum octahedral layer. Clays accelerate hemostasis by their characteristics of large surface areas, significant ion 
exchangeability, and superabsorbent capacity (37).

\section{Smectite}

WoundStat ${ }^{\mathrm{TM}}$ (WS, TraumaCure, Bethesda, Maryland, USA) is the commercial product of smectite that includes a smectite mineral and a salt of a cross-linked polyacrylic acid. With the rapid absorptivity of blood and a significant cation exchange capacity, WS can concentrate the clotting factors and platelets at the site of injury and assist in activating the intrinsic pathway thereby accelerating hemostasis (38). Despite its excellent hemostatic properties, the application of WS has brought some safety concerns, such as thrombosis risk, severe inflammatory response, neurovascular injury, and necrosis, and its use was halted in 2009 (10). Due to its safety and efficacy, smectite is still widely applied for the treatment of acute infectious diarrhea in children (39).

\section{Kaolin}

In addition to the absorption property of clays discussed above, the negative charge on the surfaces of kaolin binds to Factor XII, triggering the intrinsic pathway of the blood coagulation cascade, which in turn activates Factor XI and finally forms a fibrin clot (11). The commercial products of kaolin include QuikClot Combat Gauze ${ }^{\mathrm{TM}}$ (QCG, Z-Media, Wallingford, CT), QuikClot Combat Gauze XL (QCX, Z-Medica, Wallingford, CT), QuikClot Combat Gauze TraumaPad (QCTP, Z-Medica Corporation, Wallingford, CT), and QuikClot ${ }^{\circledR}$ Interventional $^{\mathrm{TM}}$ (QCI, Z-Medica Corporation, Wallingford, CT). Kheirabadi et al. evaluated the efficacy and the acute safety of QCG, TraumaStat, Celox D, and HemCon in an arterial hemorrhage swine model and found that QCG achieved the best hemostatic effect (40). One study has reported that QCG reduced blood loss and was more effective in hemostasis than standard gauze $(84.6 \%$ success vs. $30.8 \%$ gauze success), with the advantages of immediate use, low cost, and no severe side effects $(41,42)$. As an effective and safe hemostatic agent, QCG is recommended as the first-line treatment for life-threatening bleeding on the battlefield. QCX is similar to QCG but with a larger mass and dimension. In a standard porcine trauma bleeding model, the application of QCX was more effective in reducing the mortality of the injured animals and achieving a superior immediate hemostatic effect than QCG, owing to the increased gauze mass and a greater quantity of active ingredients (43). QCTP, a lap-top size sponge, is designed to treat large wounds. Despite the ineffectiveness of kaolin- based hemostatic agents in controlling hemorrhage in some coagulopathic animals, QCTP combined with negativepressure wound therapy was effective in stopping lethal coagulopathic bleeding in large soft tissue wounds (44). Moreover, QCTP was also used for patients undergoing spinal deformity surgery and was effective in reducing intraoperative blood loss and transfusion volume (45). QCI, a pro-coagulant kaolin-coated nonwoven gauze, can be used to control surface bleeding at an injured vascular site combined with firm manual compression. When applied in patients undergoing radial closure after percutaneous interventions, QCI, assisted with short-time compression, reduced the occurrence of radial artery occlusion $(46,47)$.

\section{Polysaccharide-based hemostatic materials}

Polysaccharides, the form in which most natural carbohydrates occur, have a branched or linear molecular structure. With their characteristics of low cost, abundant resources, good biocompatibility, and no risk of immune responses, polysaccharide-based materials have been extensively investigated as hemostatic agents, including chitosan, starch, cellulose, and alginate. However, their limited hemostatic efficacy has hampered their wider use. With the development of chemical and physical techniques, a greater number of polysaccharide-based hemostatic materials have been identified.

\section{Chitosan}

Chitosan is a natural, positively charged polysaccharide, and the deacetylated form of chitin (a natural polysaccharide) is found abundantly in shellfish. Chitosan has been widely used in biomedical areas because of its excellent non-immunogenicity and antimicrobial properties, and its good biocompatibility and biodegradability (48). Its hemostatic effects take place via the comprehensive action of three mechanisms: (I) Aggregation of red blood cells (RBCs). Positively charged glucosamine on chitosan can attract negatively charged RBCs to agglutinate, which thereby promotes coagulation independent of the classical coagulation cascade (49); (II) Stimulation of platelets. Chitosan is effective in stimulating platelet adhesion and aggregation, possibly by increasing $\mathrm{Ca}^{2+}$ mobilization and enhancing the expression of the GPIIb / III complex on the surfaces of platelets (50); (III) Alteration of the structure of fibrinogen. The mechanism of chitosan may be associated with the electrostatic forces after the ionization of chitosan, 
resulting in changes in the structure and function of fibrinogen (51). Moreover, chitosan with different molecular weights $(\mathrm{Mw})$ and various degrees of deacetylation (DDA) endows the material with different hemostatic effects. It is reported that chitosan should not be immobilized to a single $\mathrm{Mw}$ and a single DDA but is best used as mixed chitosan with an $\mathrm{Mw}$ of 8.6-247 kDa and a DDA of 75-88\% (52).

Currently, several FDA-approved chitosan-based hemostatic products are commercially available, including HemCon ${ }^{\circledR}$ Bandage (HemCon Medical Technologies Inc., Portland, OR, USA), Celox ${ }^{\circledR}$ (MedTrade Products Ltd., Cheshire, UK), and TraumaStat ${ }^{\circledast}$ (Ore-Medix, LLC Company, Lebanon, OR, USA). The HemCon ${ }^{\circledR}$ Bandage uses freeze-dried chitosan as the raw material. Because of the bandage compression and the hemostatic properties of chitosan, effective hemostasis is achieved within 2 minutes. However, the HemCon ${ }^{\circledR}$ Bandage needs to be removed within 48 hours and is difficult to use for deep or small wounds due to its rigidity. Celox ${ }^{\circledR}$, comprised of chitosan particles, avoids the rigidity shortcoming and has a better hemostatic effect compared with the HemCon ${ }^{\circledR}$ Bandage. Moreover, Celox ${ }^{\circledR}$ is also suitable for patients with coagulation dysfunction. TraumaStat ${ }^{\circledR}$, a hemostatic gauze synthesized from chitosan, silicon dioxide, and polyethylene, has a larger specific surface area, which significantly increases the contact area with the wound. TraumaStat is also more flexible and can be applied to various types of wounds (53). Recent research on modified chitosan or chitosan-based composite materials for hemostasis is depicted in Table 2.

\section{Starch}

Starch is a polysaccharide comprising glucose monomers joined in $\alpha-1,4$ linkages. Microporous polysaccharide hemisphere (MPH), a hydrophilic plant polysaccharide hemostatic agent, accelerates the clotting processes by absorbing water from the blood and concentrating platelets and coagulation proteins (63). It is reported that MPH may reduce seroma after mastectomy in rats, but a prospective randomized clinical trial reported no difference in the duration and amount of seroma drainage related to the use of MPH following mastectomy $(64,65)$. HemoStase (CryoLife, Inc, Kennesaw, Georgia) and Arista (Medafor Inc., Minneapolis, MN, US) are the commercially available hemostatic agents derived from starch. More recently, it was reported that MPH, combined with mesoporous zinccalcium silicate, significantly improved water absorption capability and degradability with excellent hemostatic and antibacterial properties (66).

\section{Cellulose}

Cellulose is a carbohydrate forming the skeleton of most plant structures and plant cells. It is the most abundant polysaccharide in nature and is also the source of dietary fiber. Natural cellulose is insoluble in water, but oxidized cellulose (OC), an absorbable oxidation product of cellulose, can be either regenerated to form organized fibers (oxidized regenerated cellulose, ORC) or remain non-regenerated with unorganized fibers before oxidation (oxidized nonregenerated cellulose, ONRC). After the oxidization process, cellulose acquires hemostatic and bactericidal properties. The low $\mathrm{pH}$ generated by carboxylic acid can activate platelets to stimulate the formation of a temporary platelet plug.

Additionally, bactericidal properties are also attributed to the low $\mathrm{pH}$, under which most bacteria cannot survive. Compared to ORC, ONRC has a greater surface area due to the frayed fibers, an equivalent bactericidal effect, and provides superior hemostatic performance in vivo (18). However, another study showed that both the oxidation degree and regeneration process might affect the bactericidal activity, hemostatic efficiency, and the cytotoxicity of ORC and ONRC (67). Based on their ready-to-use, good biocompatibility, and antibacterial properties, various commercially available products are derived from regenerated and non-regenerated cellulose, such as SURGICEL ${ }^{\circledR}$ (Johnson and Johnson, West Somerville, New Jersey). and Traumastem (Baxter Health Care, Deerfield, Illinois). A compendium of scientific literature has summarized the evidence supporting the efficacy and safety of the SURGICEL ${ }^{\circledR}$ family of absorbable hemostats. The SURGICEL ${ }^{\circledR}$ family includes four products: SURGICEL ${ }^{\circledR}$ Original, SURGICEL ${ }^{\circledR}$ Fibrillar $^{\mathrm{TM}}$, SURGICEL ${ }^{\circledR}$ Snow $^{\mathrm{TM}}$, and SURGICEL ${ }^{\circledR} \mathrm{Nu}-$ $\mathrm{knit}^{\circledR}$. SURGICEL ${ }^{\circledR}$ Original has been widely used for more than 50 years with proven safety and efficacy and has bactericidal properties. SURGICEL ${ }^{\circledR}$ Fibrillar $^{\mathrm{TM}}$ is versatile because its easily separated layers are customizable, allowing for precise placement. SURGICEL ${ }^{\circledR}$ Snow $^{\mathrm{TM}}$ is more innovative and offers enhanced hemostasis with better conformability, handling, and tissue adherence compared with SURGICEL ${ }^{\circledR}$ Original. SURGICEL ${ }^{\circledR} \mathrm{Nu}-\mathrm{knit}^{\circledR}$ has high tensile strength and thickness, allowing it to hold the suture. The SURGICEL ${ }^{\circledR}$ family has been widely used in 
Table 2 The recent research of modified chitosan or chitosan-based composite materials for hemostasis

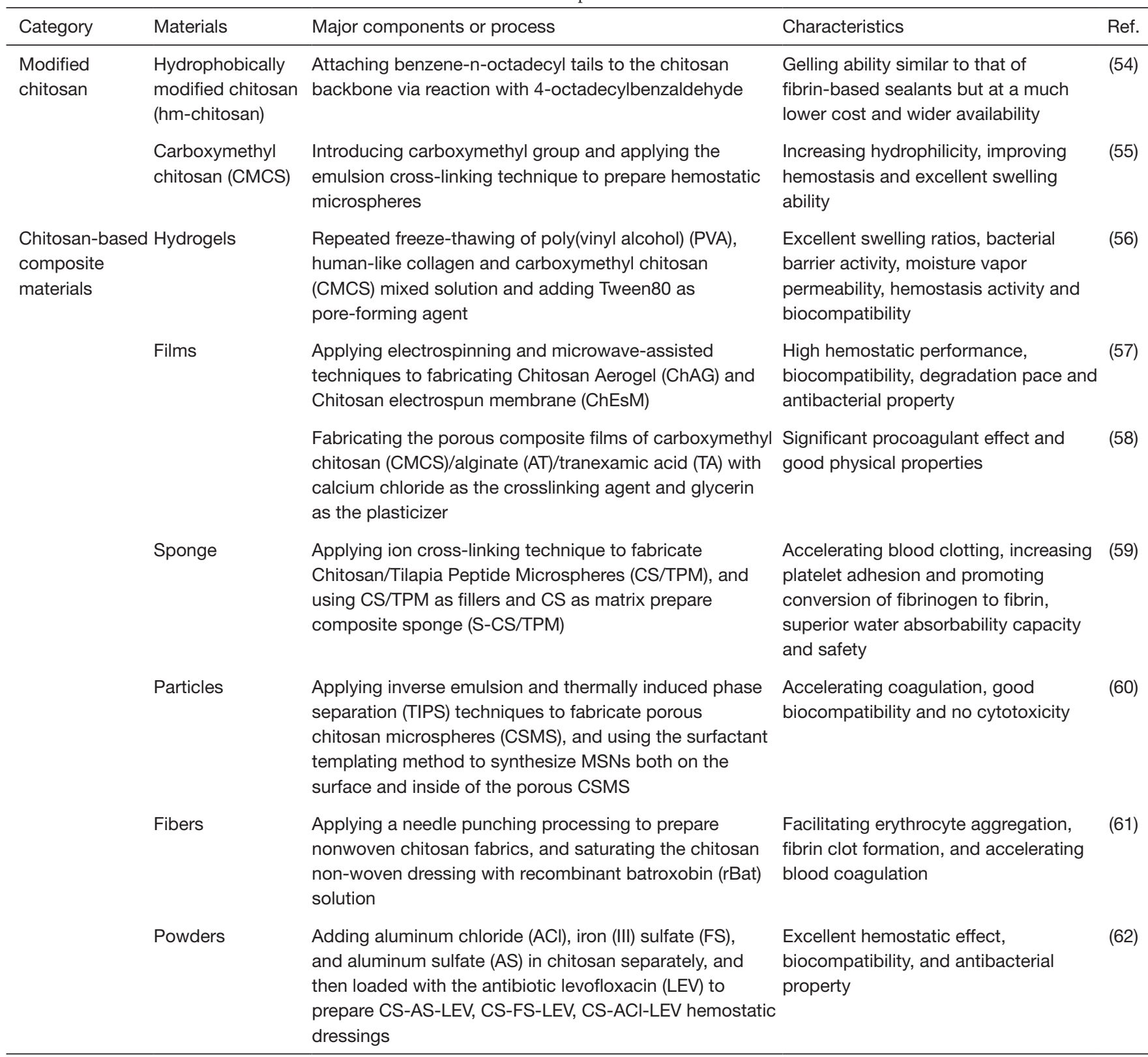

surgical operations (68). Although SURGICEL ${ }^{\circledR}$ products are generally effective, bioabsorbable hemostatic materials, there have been some safety concerns when applied in clinical treatment, including delayed absorption, cord compression, and granuloma/neoplasia, among others (69). Therefore, several practical suggestions for the safe use of OC have been summarized, including removal after hemostasis has been achieved, use of a small quantity in situ, and documentation in the surgical report (70).
Halloysite $\left[\mathrm{Al}_{2} \mathrm{Si}_{2} \mathrm{O}_{5}(\mathrm{OH})_{4} \cdot 2 \mathrm{H}_{2} \mathrm{O}\right]$, a naturally occurring aluminosilicate nano-clay, has exhibited good biocompatibility and promotion of blood coagulation. For a better effect, combined cellulose-halloysite hemostatic nanocomposite fibers (CHNFs) were fabricated by using a one-step wet-wet electrospinning process. Due to the increased specific surface area and greater quantities of the active ingredient (7-fold greater clay loading), CHNFs achieved faster human plasma coagulation and bovine 
whole blood coagulation than commercial QCG (71). Also, a recent study combined oxidized cellulose with chitosan and collagen, developing a novel hemostatic nanocomposite with satisfying biodegradability, antibacterial qualities, and efficient procoagulant properties (3).

\section{Alginate}

Alginate is a naturally occurring polysaccharide typically obtained from all brown algae species and some species of bacteria. Its biocompatibility, low toxicity, and relatively low cost are widely used for many biomedical applications. It has been demonstrated that divalent or polyvalent cations, such as $\mathrm{Ca}^{2+}$, can crosslink soluble sodium alginate into insoluble alginate. Once calcium alginate (CA) comes into contact with blood, $\mathrm{Ca}^{2+}$ acts as a procoagulant to activate the coagulation process. In fact, alginate does not possess an inherent hemostatic property in the classical sense, but alginate wound dressings provide a physiologically moist microenvironment, prevent bacterial infection at the injured site, and facilitate wound healing $(72,73)$. To improve its limited hemostasis, Pan and colleagues fabricated microspheres containing zinc alginate ( $\mathrm{ZnAlg}$ ) and chitosan (CS@ZnAlg microspheres), which clotted the blood much faster in vitro and in vivo (74).

\section{Biologically derived homeostatic materials}

Biologically derived hemostatic agents can directly increase coagulation factors at the topical injury site, activate blood clotting, and thereby present an outstanding hemostatic efficacy. These materials participating at the end of the coagulation cascade to form a fibrin clot are called active agents, such as thrombin and fibrinogen.

\section{Thrombin}

Thrombin, an enzyme (proteinase) in shed blood, forms from prothrombin through the action of the prothrombinase complex in the common pathway of the coagulation cascade (75). Thrombin performs essential functions in blood coagulation and platelet aggregation: (I) Direct action with fibrinogen. As discussed above, thrombin converts fibrinogen into fibrin to form clots; (II) Indirect effects are mediated via other clotting factors. This effect creates a feedback loop: activating the cofactors FV, FVIII, and FX to enhance its generation and activating FXIII to crosslink fibrin into a stable plug $(76,77)$. Three sources of thrombin have been used commercially: bovine plasma (Thrombin-JMI, marketed by King Pharmaceuticals, Inc), human pooled plasma (Evithrom, Omrix, Johnson \& Johnson), and the recombinant human thrombin (rhThrombin) (Recothrom, ZymoGenetics, Inc).

Animal-derived plasma, mostly from bovine thrombin, may not only lead to xenogeneic immune responses and postoperative complications but also possibly transmits blood-borne pathogens such as bovine spongiform encephalopathy (BSE). Even human-derived plasma can significantly reduce immunological reactions. The potential risk of transmitting bloodborne pathogens such as HIV and hepatitis $\mathrm{B}$ and $\mathrm{C}$ remains. rhThrombin has similar efficacy to animal- or human-derived plasma thrombin but has a significantly lower risk of an immunologic impact. In phase 3, randomized, double-blind comparative study of the efficacy and safety of rhThrombin and bovine thrombin used in surgical hemostasis, rhThrombin was found to cause fewer immunological reactions and had similar efficacy and safety to bovine thrombin (78). The phase 4 rhThrombin trial's immunogenicity and safety suggested that patients with known previous exposure may still be safely re-exposed to this topical rhThrombin (79).

\section{Fibrin}

Fibrin is an insoluble protein that forms a three-dimensional protein network when the blood protein fibrinogen interacts with thrombin. Commercially available fibrin products named 'fibrin sealants' contain two primary components (Figure 4): component one contains human-derived fibrinogen, and component two contains thrombin. Besides the two primary components, other active components usually added to fibrin sealants are $\mathrm{Ca}^{2+}$ and anti-fibrinolytic agents like aprotinin (80). The hemostatic mechanisms of fibrin sealants are: (I) Acting as a hemostat, fibrin sealants can increase coagulation factors in vivo and activate blood clotting; (II) acting as a sealant, fibrin sealants create a sealing barrier that physically prevents blood loss from a structure; and (III) acting as an adhesive, fibrin sealants are capable of self-polymerizing and adhering structures together when applied in a dry field. When used in potentially injured blood vessels, neither sealants nor adhesives possess an inherent hemostatic property to cause blood clotting but can be used as hemostats by gluing the injured site of the vessel and preventing bleeding. Conclusively, fibrin sealant is the only commercially available FDA-approved material for clinical use in all three of these 

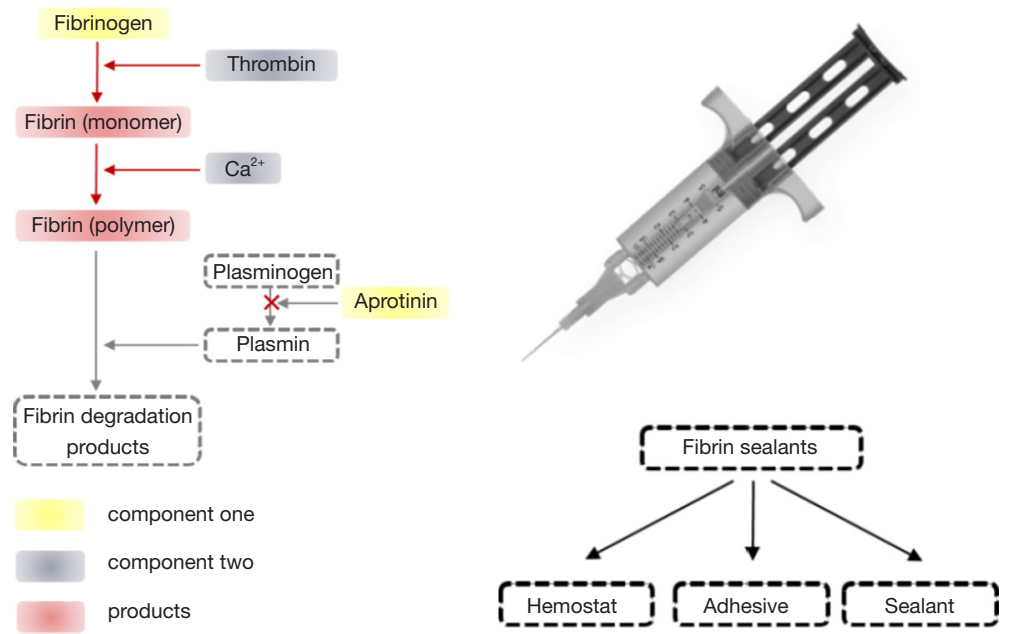

Figure 4 Two primary components of fibrin sealant (left figure) and its application (right figure).

groups: hemostats, sealants, and adhesives (Figure 4) (23). Several fibrin sealants are commercially available, such as Tisseel (Baxter Health Care, Deerfield, Illinois), Evicel (Johnson and Johnson, West Somerville, New Jersey), Vitagel (Orthovita, Malvern, Pennsylvania), Evarrest (Omrix Biopharmaceuticals, Israel), and ARTISS (Baxter Health Care, Deerfield, Illinois). Fibrin sealants have been widely used in surgical procedures to achieve hemostasis, such as elective retroperitoneal or intraabdominal surgery, elective hepatectomy, vascular surgery, etc. (81-84). On the other hand, no significant benefits or side effects were observed from a recent multicenter randomized controlled trial to evaluate the effect of fibrin sealants in total knee replacement surgery (85).

Despite these widely used hemostatic materials, certain safety concerns need to be noted. The major concern relates to bloodborne diseases caused by human-derived plasma. Based on this limitation, a safe, similar-efficacy and low-cost recombinant human fibrin sealant (rhFS) may have a greater potential for clinical use (86). In contrast to the routinely used liquid fibrin sealants, Fibrocaps (Raplixa; ProFibrix BV, a subsidiary of The Medicines Company) is a novel, dry-powder fibrin sealant used for the control of surgical bleeding. Fibrocaps, a ready-to-use powder, needs to be stored at room temperature and can be applied directly via a spray device. A recent study indicated that Fibrocaps was effective and safe as an adjunct to treat mild to moderate surgical bleeding in patients undergoing a wide variety of surgical procedures in a phase 3 , international, randomized, single-blind, controlled trial (87).

\section{Collagen-based materials}

Collagen-based materials include three types of hemostatic agents: collagen, gelatin, and microfibrillar collagen. Collagen, mostly present in fibrous connective tissues such as bones, skin, muscles, tendons, and ligaments, serves an essential structural role in providing tensile strength and flexibility for tissues and organs. Gelatin can be formed by thermal denaturation or irreversible hydrolysis of collagen, and microfibrillar collagen is a new physical form of collagen, which is derived by converting bovine corium collagen into a partial hydrochloric acid amine salt of bovine collagen $(88,89)$.

\section{Collagen}

At least 29 types of collagen have been identified to date and classified primarily according to their structures, with over $90 \%$ of those in the body classified as type I. The excellent characteristics of collagen include easy extractability, low cost, and good biocompatibility, which make collagen an attractive biomaterial for developing medical products and therapeutic devices (89). The roles of collagen in thrombosis and hemostasis are as follows: (I) indirect effects mediated via platelets. When blood vessels remain intact, blood will flow smoothly over the subendothelial structures constituting the connective tissue which contains a high percentage of collagen. Once exposed to blood flow, collagen provides the matrix structure for platelet adhesion, aggregation, and activation; (II) direct interaction with clotting factors. Collagen activates the intrinsic pathway of the coagulation cascade through three clotting factors: the 
activation of factor XII, the binding of factor IX to collagen type IV, and the interaction with the von Willebrand factor (vWF) (90). Compared to OC-based patches, collagenbased patches have more reliable mechanical properties and can reduce swelling and adhesion formation in the body (91). A representative, commercially available collagen product is Stypro ${ }^{\circledR}$ hemostatic sponge (Curasan AG, Kleinostheim, Germany), derived from bovine collagen. The microporous and inter-connective structure of the sponge stimulates the coagulation cascade through its super absorption capacity (up to 50 times its weight). Another commercially available collagen product is HEMOBLAST ${ }^{\mathrm{TM}}$ Bellows (Biom'up, Lyon, France), which is a powder composed of porcinederived collagen, bovine-derived chondroitin sulfate, and human-derived thrombin. The powder has several excellent qualities, such as good biocompatibility and reabsorption within 4 weeks, and it is easy and ready to use (26).

Oxidized microcrystalline cellulose (OMCC), a new type of oxidized regenerated cellulose, is regarded as an affordable and effective hemostat with properties of biological safety, low cost, and an excellent hemostatic effect. Recently, researchers have fabricated a composite containing single-collagen sponges and OMCC to improve the hemostatic ability of collagen. The results showed that the composite reduced the lengths of the activated partial thromboplastin time (APTT) and thrombin time (TT) in vitro, and presented a rapid hemostatic effect in vivo (92). Commercially available collagen-based agents, usually derived from bovine and swine, carry the potential risk of transmitting diseases such as BSE and transmissible spongiform encephalopathy (TSE), and porcine collagen can also present religious objections in certain cultures. Based on these inevitable problems, jellyfish collagen was extracted from Rhopilema esculentum Kishinouye ( $R$. esculentum), which is one of the most abundant species of jellyfish in China. Due to their porous structure and higher water absorption rate, jellyfish collagen sponges exhibited rapid hemostasis and a greater decrease in the amount of blood loss than medical gauze (93).

\section{Gelatin}

Gelatin, prepared from purified pork skin gelatin or bovine-derived gelatin, is available in sponge, powder, or granular forms and can be absorbed within 4 to 6 weeks. Compared with animal-derived fibrin or collagen, gelatin is superior in its biocompatibility, biodegradability, and low immunogenicity. Gelatin materials not only absorb many times their weight of blood but also concentrate clotting factors and platelets at the site of injury. After absorbing water, gelatin material swells, which in turn provides a compressive effect at the wound site. Additionally, gelatin can provide a structural matrix for clotting (94). To improve gelatin's thermal and mechanical stability, a chemical crosslinker can be used to react with the amine groups in gelatin, among which glutaraldehyde (GLA) is the most widely used and relatively inexpensive crosslinker. It has been demonstrated that gelatin sponges containing $1 \% \mathrm{w} / \mathrm{v}$ gelatin and $0.5 \% \mathrm{w} / \mathrm{v}$ glutaraldehyde had good mechanical strength, improved water absorption ability, and hemostatic effectiveness without any risk of cytotoxicity (95). Currently, there are several commercially available gelatinbased products, such as GelFoam (Pfizer, New York, New York), FloSeal (Baxter Health Care, Deerfield, Illinois), and Surgiflo (Johnson and Johnson, West Somerville, New Jersey). GelFoam, a solid gelatin-based product, can swell up to twice its size after absorbing water from the blood, which provides a tamponade effect to stop bleeding. However, the tamponade effect may cause compression-related side effects, such as compression of nerves in the spinal cord (27). FloSeal, a liquid gelatin-based product, contains a proprietary blend of a gelatin matrix and topical thrombin and is prepared by mixing them immediately before use. FloSeal has a wide range of clinical applications not only because of its advantage of a tamponade effect but also because its liquid form allows flexibility in its application to irregular wounds, resulting in intimate contact of FloSeal with the site of bleeding. Furthermore, FloSeal can be safely used in limited surgical spaces, where high concentrations of thrombin achieve effective hemostasis (21).

Recently, due to their controllable morphology and surface properties, nanofibrous materials have had a wide range of applications in biomedical areas, such as wound dressing, drug delivery, tissue engineering, and hemostasis (96). Xie et al. fabricated an injectable and super-elastic nanofiber rectangle matrix ("peanut") coated with gelatin. They demonstrated that the "peanut" presented effective hemostasis in a porcine liver injury model by absorbing water and accelerating the clotting processes (97).

\section{Microfibrillar collagen}

Microfibrillar collagen, made from purified bovine collagen and applied in a dry, loose flour form, is one of the most widely used topical hemostatic agents. Microfibrillar collagen can be applied to wet environments such as bleeding wounds. However, the need for gloves or surgical instruments in its use limits its further application. Several 
different products are available, including Avitene, Avitene Flour, EndoAvitene, Avitene Ultrafoam, Avitene UltraWrap (Davol, Warwick, Rhode Island), Instat (Johnson and Johnson, West Somerville, New Jersey), Helitene (Integra, Plainsboro, New Jersey), and Helistat(Integra, Plainsboro, New Jersey). A single-center, randomized clinical trial comparing the hemostatic effectiveness of microfibrillar collagen and $\mathrm{OC}$ in arterial bypass surgery has shown that microfibrillar collagen stopped suture hole bleedings significantly faster than oxidized cellulose (28).

\section{Bovine albumin}

Gelatin-resorcinol-formaldehyde-glutaraldehyde (GRFG) glue, also known as "French glue", comprises a formaldehyde/glutaraldehyde mixture and a solution of gelatin, resorcinol, and calcium chloride. GRFG bonds to tissue covalently and tightly, but the same biochemical reactions may bring cytotoxicity, tissue necrosis, and other late complications. Although GRFG has been widely used in Europe and Asia, it has not yet been approved by the FDA for clinical use in the USA, mainly due to its side effects, including the high concentrations of formaldehyde-associated tissue toxicity. BioGlue, composed of $45 \%$ purified bovine serum albumin (BSA) and $10 \%$ glutaraldehyde, has been approved by the FDA for use as a tissue adhesive, generally applied to an anastomosis before perfusion (98). Without formaldehyde in its ingredient, BioGlue is thought to cause less toxicity. When applied, it creates a mechanical sealant by bonding to the tissue proteins at the injury site. However, it works in a bloodless and dry field. Therefore, BioGlue is generally used as an adjunct following closure of large blood vessels, but not used to control active bleeding. Although BioGlue provides a tight mechanical barrier and causes less toxicity, it still carries the potential risk of tissue injury, mass effect, and embolic complications (30).

Whey protein, comprised mainly of $\beta$-lactoglobulin, $\alpha$-lactalbumin, and BSA can be used as a protein polymer to react with glutaraldehyde. Researchers fabricated a novel tissue adhesive by replacing BSA with whey protein, due to the abundant source and low cost of whey protein. The results showed that this novel adhesive presented a comparable adhesive strength to BioGlue ${ }^{\circledR}$ (99).

\section{Synthetically derived hemostatic materials}

Synthetic hemostatic materials are another type of hemostatic material that can be produced industrially and can be formulated with other adjuncts to improve their biocompatibility, stability, and clinical performance. However, the cytotoxicity and non-biodegradability of synthetic hemostatic materials are potential problems, which should be noted in future development efforts.

\section{Polyethylene glycol}

Polyethylene glycol (PEG), is a multi-arm copolymer with an N-hydroxysuccinimide (NHS) ester at each end. Due to its excellent biocompatibility, high water absorption, ease of binding with biomolecules, and multiple gelation mechanisms, PEG is widely used in the formation of hydrogels. PEG-based tissue sealants have been extensively studied in the treatment of air leakage, acute aortic dissection, and suture hole bleeding involved in different surgical procedures (100). Currently, two PEG-based tissue sealants are available. CoSeal (Baxter Health Care, Deerfield, Illinois), an FDA-approved sealant, has been used for some urologic procedures, while Duraseal (Covidien, Norwalk, Connecticut) is indicated for dural sealing (22).

Several PEG-based hydrogel adhesives were synthesized and studied recently. In particular, three hydrogels with different amounts of Schiff-base moieties from 4-arm-PEGNH2, 4-arm-PEG-NHS, and 4-arm-PEG-CHO were constructed. 4-arm-PEG was chosen to build well-defined hydrogel networks that yield high mechanical strength, while Schiff base cross-links can optimize the strength and antibacterial effects. As a result, the synthesized hydrogels exhibited porous structures, excellent mechanical strength, a high swelling ratio, and antibacterial effects, which are favorable for hemostasis in critical situations (101). PEGbased adhesives often require irradiation to polymerize their components, which is impractical for many organs of the body and limits their application in emergencies.

\section{Cyanoacrylate}

Cyanoacrylate monomers, in low-viscosity liquid form, are synthesized by the condensation of cyanoacetate and formaldehyde in conditions of heat and a vacuum. When in contact with various anionic substances, such as blood, the basic cyanoacrylate monomer polymerizes into long chains forming the adhesive film that glues the wound and holds the apposed edges together. The adhesive does not need to be removed after use since the adhesive substance generally sloughs off within 5 to 10 days as the epidermis 
regenerates (32). Despite providing a hemostatic effect on application, cyanoacrylate adhesives do not possess inherent hemostatic properties to cause blood clotting, but rather block holes in the vessel to prevent bleeding. Cyanoacrylate topical adhesives are recommended for sealing low-tension wounds that are clean and dry but cannot be used alone to close high-tension wounds. The cyanoacrylate alkyl side chain's length and complexity can directly affect their mechanical strength and other physical properties. Short, straight-chain derivatives (ethyl or butyl cyanoacrylate) are superior to long-chain derivatives (octyl-cyanoacrylate) in terms of forming tighter and stronger bonds, while long-chain derivatives have less toxic effects and reduce inflammation (102). There are currently two FDA-approved cyanoacrylate-based sealants available, 2-octyl cyanoacrylate (marketed as Dermabond by Johnson and Johnson), and butyl-2-cyanoacrylate, (marketed as Histoacryl by Braun, Melsungen, Germany), which are limited to skin closure use. Clinically, ethyl-2-cyanoacrylate is cost-effective, timesaving, and successful in repair satisfaction when used in a children's emergency department (103). Moreover, octyl-2cyanoacrylate has been used effectively for cleft lip closure with the advantages of a relatively quick and painless procedure, with less risk of tissue reaction and wound infection (104). However, the possibility of cell toxicity, foreign body reaction, and low tensile strength should be noted (105).

In general, this review briefly summarizes hemostatic materials in terms of their structure, mechanisms of actions, advantages, and disadvantages, commercially available products and their applications, as well as recent developments (Table 3). Moreover, several promising

Table 3 The brief introduction of hemostatic materials

\begin{tabular}{|c|c|c|c|c|c|c|}
\hline Category & Materials & Mechanism & Advantage & Disadvantage & Product & Application \\
\hline \multicolumn{2}{|c|}{$\begin{array}{l}\text { Inorganic based Zeolite } \\
\text { hemostatic } \\
\text { materials }\end{array}$} & Water absorption & $\begin{array}{l}\text { Rapidly achieving } \\
\text { hemostasis }\end{array}$ & Exothermic reaction & ACS+ & $\begin{array}{l}\text { Battle Injury First } \\
\text { Aid }\end{array}$ \\
\hline & Smectite & $\begin{array}{l}\text { Water absorption; } \\
\text { cation exchange } \\
\text { ability to stimulate } \\
\text { intrinsic pathway }\end{array}$ & $\begin{array}{l}\text { Excellent hemostatic } \\
\text { properties }\end{array}$ & $\begin{array}{l}\text { Thrombosis risk; severe } \\
\text { inflammatory response; } \\
\text { neurovascular injury and } \\
\text { necrosis }\end{array}$ & WoundStat & unavailable \\
\hline & \multirow[t]{3}{*}{ Kaolin } & \multirow{3}{*}{$\begin{array}{l}\text { Water absorption; } \\
\text { activation Factor } \\
\text { XII }\end{array}$} & \multirow{3}{*}{$\begin{array}{l}\text { Various hemostatic } \\
\text { mechanisms; low } \\
\text { cost; safe }\end{array}$} & \multirow[t]{3}{*}{ Need to remove } & QCG & QCG and QCX for \\
\hline & & & & & QCX & $\begin{array}{l}\text { battlefield; QCTP } \\
\text { for spinal deformity }\end{array}$ \\
\hline & & & & & QCTP & $\begin{array}{l}\text { surgery; QCI for } \\
\text { percutaneous }\end{array}$ \\
\hline \multirow{5}{*}{$\begin{array}{l}\text { Polysaccharide } \\
\text { based } \\
\text { hemostatic } \\
\text { materials }\end{array}$} & \multirow{2}{*}{ Chitosan } & \multirow{2}{*}{$\begin{array}{l}\text { Aggregation of red } \\
\text { blood cells; } \\
\text { stimulation of } \\
\text { platelets; affection } \\
\text { the structure of } \\
\text { fibrinogen }\end{array}$} & \multirow{2}{*}{$\begin{array}{l}\text { Various hemostatic } \\
\text { mechanisms; } \\
\text { non-immunogenicity; } \\
\text { antimicrobial; } \\
\text { degradability }\end{array}$} & \multirow{2}{*}{$\begin{array}{l}\text { Inadaptation for deep } \\
\text { and small injury site }\end{array}$} & Celox & \multirow{2}{*}{$\begin{array}{l}\text { Battlefield and } \\
\text { pre-hospital setting }\end{array}$} \\
\hline & & & & & TraumaStat & \\
\hline & \multirow[t]{2}{*}{ Starch } & \multirow[t]{2}{*}{ Water absorption } & \multirow{2}{*}{$\begin{array}{l}\text { Non-immunogenic; } \\
\text { bio-absorption }\end{array}$} & \multirow{2}{*}{$\begin{array}{l}\text { Limited hemostatic } \\
\text { efficacy }\end{array}$} & Arista & \multirow{2}{*}{$\begin{array}{l}\text { Widely used in } \\
\text { surgery; possible } \\
\text { reducing seroma } \\
\text { after mastectomy }\end{array}$} \\
\hline & & & & & Hemostase & \\
\hline & Cellulose & $\begin{array}{l}\text { Activating platelets; } \\
\text { generating blood } \\
\text { cells; water } \\
\text { absorption; }\end{array}$ & $\begin{array}{l}\text { Bactericidal } \\
\text { properties }\end{array}$ & Cytotoxicity & Surgicel & $\begin{array}{l}\text { Widely used in } \\
\text { surgery }\end{array}$ \\
\hline
\end{tabular}

Table 3 (continued) 
Table 3 (continued)

\begin{tabular}{|c|c|c|c|c|c|c|}
\hline Category & Materials & Mechanism & Advantage & Disadvantage & Product & Application \\
\hline \multirow[t]{4}{*}{$\begin{array}{l}\text { Biologically } \\
\text { derived } \\
\text { homeostatic } \\
\text { materials }\end{array}$} & thrombin & $\begin{array}{l}\text { Direct action with } \\
\text { fibrinogen; Indirect } \\
\text { effects mediated } \\
\text { via other clotting } \\
\text { factors }\end{array}$ & $\begin{array}{l}\text { Excellent hemostatic } \\
\text { performance }\end{array}$ & $\begin{array}{l}\text { Xenogeneic immune } \\
\text { response; transmitting } \\
\text { bloodborne pathogens; } \\
\text { high cost }\end{array}$ & $\begin{array}{l}\text { Recothrom } \\
\text { Thrombin-JMI } \\
\text { Evithrom }\end{array}$ & $\begin{array}{l}\text { Widely used in } \\
\text { surgery }\end{array}$ \\
\hline & fibrin & $\begin{array}{l}\text { Increase } \\
\text { coagulation factors; } \\
\text { creating a sealing } \\
\text { barrier; adhering } \\
\text { structures together }\end{array}$ & $\begin{array}{l}\text { hemostats, sealants } \\
\text { and adhesives }\end{array}$ & $\begin{array}{l}\text { Transmitting bloodborne } \\
\text { pathogens; high cost }\end{array}$ & $\begin{array}{l}\text { Tisseel } \\
\text { Evicel } \\
\text { Vitagel } \\
\text { Evarrest } \\
\text { ARTISS }\end{array}$ & $\begin{array}{l}\text { Widely used in } \\
\text { surgery }\end{array}$ \\
\hline & Gelatin & Water absorption & $\begin{array}{l}\text { Providing tamponade } \\
\text { effect; } \\
\text { low immunogenicity }\end{array}$ & $\begin{array}{l}\text { Compression-related } \\
\text { side effects }\end{array}$ & $\begin{array}{l}\text { Floseal } \\
\text { Surgiflo } \\
\text { Gelfoam }\end{array}$ & $\begin{array}{l}\text { Gelfoam not for } \\
\text { spinal and } \\
\text { neurosurgery }\end{array}$ \\
\hline & $\begin{array}{l}\text { Microfibrillar } \\
\text { Collagen }\end{array}$ & Activation platelets & $\begin{array}{l}\text { Adhesive to wet } \\
\text { environment }\end{array}$ & $\begin{array}{l}\text { Adherence to gloves } \\
\text { and instruments }\end{array}$ & $\begin{array}{l}\text { Avitene Flour; } \\
\text { EndoAvitene; } \\
\text { Avitene Ultrafoam; } \\
\text { Avitene UltraWrap }\end{array}$ & $\begin{array}{l}\text { Widely used in } \\
\text { surgery }\end{array}$ \\
\hline $\begin{array}{l}\text { Synthetically } \\
\text { derived } \\
\text { hemostatic } \\
\text { materials }\end{array}$ & Cyanoacrylate & Physical barrier & $\begin{array}{l}\text { Sealing low-tension } \\
\text { wounds }\end{array}$ & $\begin{array}{l}\text { Use on dry surface; not } \\
\text { for high-tension wounds }\end{array}$ & $\begin{array}{l}\text { Dermabond } \\
\text { Histoacryl }\end{array}$ & skin closure \\
\hline
\end{tabular}

products show great potential in clinical use, and ongoing clinical trials are being conducted to explore their safety and efficacy in different areas (Table 4).

\section{Future outlook}

Improved hemostatic materials show great potential for clinical use, but few have been translated from laboratory studies to clinical applications. As we know, the manufacture of novel products and the continuous optimization of their hemostatic properties are extremely important for controlling bleeding and reducing mortality. Therefore, future research should combine different materials and technologies to identify an ideal hemostatic product.

Firstly, due to the limited hemostatic performance of single-component hemostatic materials, composite 
Table 4 Ongoing clinical trials in recent decade

\begin{tabular}{|c|c|c|c|}
\hline Study & $\begin{array}{l}\text { ClinicalTrials.gov } \\
\text { identifier }\end{array}$ & Conditions & Interventions \\
\hline $\begin{array}{l}\text { Hemostasis Pad Using Chitosan After Invasive } \\
\text { Percutaneous Procedures }\end{array}$ & NCT02954029 & $\begin{array}{l}\text { Percutaneous Coronary } \\
\text { Intervention }\end{array}$ & ezClot pad \\
\hline $\begin{array}{l}\text { Studying Safety \& Efficacy of Axiostat }{ }^{\circledR} \text { Dressing in } \\
\text { Acute Hemorrhage Due to Trauma-Comparative Study }\end{array}$ & NCT03035695 & $\begin{array}{l}\text { Pre- hospital Hemorrhagic } \\
\text { Control }\end{array}$ & Axiostat ${ }^{\circledR}$ \\
\hline Arista for ALT Donor Sites to Reduce Drain Output & NCT02477774 & $\begin{array}{l}\text { Anterolateral Thigh Donor } \\
\text { Sites }\end{array}$ & ARISTA \\
\hline $\begin{array}{l}\text { EndoClot for Hemostasis and Preventing } \\
\text { Post-procedure Bleeding After Endoscopic Mucosal } \\
\text { Resection }\end{array}$ & NCT01496781 & Endoscopic Hemostasis & $\begin{array}{l}\text { EndoClot }{ }^{\circledR} \text { Absorbable } \\
\text { Polysaccharide Hemostat }\end{array}$ \\
\hline Surgicel Snow in Gynecological Surgery & NCT02908841 & Laparoscopic Hysterectomy & Surgicel Snow \\
\hline $\begin{array}{l}\text { Topical rhThrombin as an Adjunct to Hemostasis } \\
\text { During Segmental Hepatectomy }\end{array}$ & NCT03611426 & Hepatectomy & $\begin{array}{l}\text { Recombinant Human } \\
\text { Thrombin }\end{array}$ \\
\hline $\begin{array}{l}\text { Blood-saving Effect of Combined Intravenous } \\
\text { Tranexamic Acid With Topical Floseal }{ }^{\circledR} \text { Application Total } \\
\text { Hip Arthroplasty }\end{array}$ & NCT03623789 & Total Hip Arthroplasty & $\begin{array}{l}\text { Floseal Combined } \\
\text { Tranexamic Acid }\end{array}$ \\
\hline $\begin{array}{l}\text { Standard of Care Versus Hemopatch }{ }^{\circledast} \text { During Liver } \\
\text { Resection }\end{array}$ & NCT03166683 & Liver Resection & Hemopatch \\
\hline $\begin{array}{l}\text { Safety and Efficacy of Fibrin Sealant Grifols as an } \\
\text { Adjunct to Haemostasis During Surgery in Paediatric } \\
\text { Subjects }\end{array}$ & NCT03461406 & $\begin{array}{l}\text { During Surgery in Pediatric } \\
\text { Subjects }\end{array}$ & Fibrin sealant grifols \\
\hline Strategy for Aortic Surgery Hemostasis & NCT03917862 & Aortic Surgery & TDM-621 (PuraStat ${ }^{\circledR}$ ) \\
\hline $\begin{array}{l}\text { Purastat }{ }^{\circledR} \text { vs. Standard Therapy for Haemostasis During } \\
\text { Endoscopic Submucosal Dissection }\end{array}$ & NCT02833558 & $\begin{array}{l}\text { Gastrointestinal } \\
\text { Haemorrhage }\end{array}$ & PuraStat $^{\circledR}$ \\
\hline
\end{tabular}

hemostatic materials containing two or more active hemostatic agents should be designed to improve their hemostatic performance.

Secondly, the comprehensive performance of hemostatic products should be improved with up-to-date technology. In addition to excellent hemostatic performance, products would be more widely used if they have additional advantages, such as antibacterial, anti-inflammatory, and rapid healing properties.

Thirdly, tissue-specific hemostatic materials and products should be developed. Novel hemostatic products should be specifically targeted for different types of tissue wounds, 
such as different shapes and depths of wounds.

Lastly, substantial interdisciplinary research efforts are necessary to conduct robust studies for the fabrication of an ideal hemostatic dressing, such as establishing and perfecting animal models of trauma, inventing effective hemostatic devices, and conducting clinical trials in multidisciplinary settings.

\section{Acknowledgments}

Funding: This work is supported by a grant from the Science and Technology Commission of the Central Military Commission (1916315ZD00900103).

\section{Footnote}

Reporting Checklist: The authors have completed the Narrative Review reporting checklist. Available at http:// dx.doi.org/10.21037/atm-20-7160

Peer Review File: Available at http://dx.doi.org/10.21037/ atm-20-7160

Conflicts of Interest: All authors have completed the ICMJE uniform disclosure form (available at http://dx.doi. org/10.21037/atm-20-7160). The authors have no conflicts of interest to declare.

Ethical Statement: The authors are accountable for all aspects of the work in ensuring that questions related to the accuracy or integrity of any part of the work are appropriately investigated and resolved.

Open Access Statement: This is an Open Access article distributed in accordance with the Creative Commons Attribution-NonCommercial-NoDerivs 4.0 International License (CC BY-NC-ND 4.0), which permits the noncommercial replication and distribution of the article with the strict proviso that no changes or edits are made and the original work is properly cited (including links to both the formal publication through the relevant DOI and the license). See: https://creativecommons.org/licenses/by-nc-nd/4.0/.

\section{References}

1. Jenkins DH, Cioffi WG, Cocanour CS, et al. Position statement of the Coalition for National Trauma Research on the National Academies of Sciences, Engineering and Medicine report, A National Trauma Care System: Integrating Military and Civilian Trauma Systems to Achieve Zero Preventable Deaths After Injury. J Trauma Acute Care Surg 2016;81:816-8.

2. Price MA, R AK, Bulger EM, et al. Building the future for national trauma research. Trauma Surg Acute Care Open 2020;5:e000421.

3. Yuan H, Chen L, Hong FF. A Biodegradable Antibacterial Nanocomposite Based on Oxidized Bacterial Nanocellulose for Rapid Hemostasis and Wound Healing. ACS Appl Mater Interfaces 2020;12:3382-92.

4. Zhang J, Xue S, Zhu X, et al. Emerging chitin nanogels/ rectorite nanocomposites for safe and effective hemorrhage control. J Mater Chem B 2019;7:5096-103.

5. Dang NC, Ardehali A, Bruckner BA, et al. Prospective, multicenter, randomized, controlled trial evaluating the performance of a novel combination powder vs hemostatic matrix in cardiothoracic operations. J Card Surg 2020;35:313-9.

6. Boulton AJ, Lewis CT, Naumann DN, et al. Prehospital haemostatic dressings for trauma: a systematic review. Emerg Med J 2018;35:449-57.

7. Welch M, Barratt J, Peters A, et al. Systematic review of prehospital haemostatic dressings. BMJ Mil Health 2020;166:194-200.

8. Ke Z, Huang Q. Haem-assisted dityrosine-cross-linking of fibrinogen under non-thermal plasma exposure: one important mechanism of facilitated blood coagulation. Sci Rep 2016;6:26982.

9. Hickman DA, Pawlowski CL, Sekhon UDS, et al. Biomaterials and Advanced Technologies for Hemostatic Management of Bleeding. Adv Mater 2018;30:10.1002/ adma.201700859.

10. Gerlach T, Grayson JK, Pichakron KO, et al. Preliminary study of the effects of smectite granules (WoundStat) on vascular repair and wound healing in a swine survival model. J Trauma 2010;69:1203-9.

11. Gegel B, Burgert J, Gasko J, et al. The effects of QuikClot Combat Gauze and movement on hemorrhage control in a porcine model. Mil Med 2012;177:1543-7.

12. Arnaud F, Tomori T, Carr W, et al. Exothermic reaction in zeolite hemostatic dressings: QuikClot ACS and ACS+. Ann Biomed Eng 2008;36:1708-13.

13. Wedmore I, McManus JG, Pusateri AE, et al. A special report on the chitosan-based hemostatic dressing: experience in current combat operations. J Trauma 2006;60:655-8.

14. Kozen BG, Kircher SJ, Henao J, et al. An alternative 
hemostatic dressing: comparison of CELOX, HemCon, and QuikClot. Acad Emerg Med 2008;15:74-81.

15. Englehart MS, Cho SD, Tieu BH, et al. A novel highly porous silica and chitosan-based hemostatic dressing is superior to HemCon and gauze sponges. J Trauma 2008;65:884-90; discussion 890-2.

16. Tschan CA, Nie M, Schwandt E, et al. Safety and efficacy of microporous polysaccharide hemospheres in neurosurgery. Neurosurgery 2011;69:ons49-63.

17. Woodworth BA, Chandra RK, LeBenger JD, et al. A gelatin-thrombin matrix for hemostasis after endoscopic sinus surgery. Am J Otolaryngol 2009;30:49-53.

18. Lewis KM, Spazierer D, Urban MD, et al. Comparison of regenerated and non-regenerated oxidized cellulose hemostatic agents. Eur Surg 2013;45:213-20.

19. Terrill PJ, Goh RC, Bailey MJ. Split-thickness skin graft donor sites: a comparative study of two absorbent dressings. J Wound Care 2007;16:433-8.

20. Foster KN, Mullins RF, Greenhalgh DG, et al. Recombinant human thrombin: safety and immunogenicity in pediatric burn wound excision. J Pediatr Surg 2011;46:1992-9.

21. Oz MC, Rondinone JF, Shargill NS. FloSeal Matrix: new generation topical hemostatic sealant. J Card Surg 2003;18:486-93.

22. Wheat JC, Wolf JS, Jr. Advances in bioadhesives, tissue sealants, and hemostatic agents. Urol Clin North Am 2009;36:265-75, x.

23. Spotnitz WD. Fibrin Sealant: The Only Approved Hemostat, Sealant, and Adhesive-a Laboratory and Clinical Perspective. ISRN Surg 2014;2014:203943.

24. Foster K, Greenhalgh D, Gamelli RL, et al. Efficacy and safety of a fibrin sealant for adherence of autologous skin grafts to burn wounds: results of a phase 3 clinical study. J Burn Care Res 2008;29:293-303.

25. Awada H, Geller JC, Brunelli M, et al. Pocket related complications following cardiac electronic device implantation in patients receiving anticoagulation and/ or dual antiplatelet therapy: prospective evaluation of different preventive strategies. J Interv Card Electrophysiol 2019;54:247-55.

26. Bruckner BA, Ngo U, Ramchandani M, et al. Application techniques of a novel hemostat in cardiac operations: HEMOBLAST. J Card Surg 2019;34:849-53.

27. Schonauer C, Tessitore E, Barbagallo G, et al. The use of local agents: bone wax, gelatin, collagen, oxidized cellulose. Eur Spine J 2004;13 Suppl 1:S89-96.

28. Qerimi B, Baumann P, Hüsing J, et al. Collagen hemostat significantly reduces time to hemostasis compared with cellulose: COBBANA, a single-center, randomized trial. Am J Surg 2013;205:636-41.

29. Milkes DE, Friedland S, Lin OS, et al. A novel method to control severe upper GI bleeding from metastatic cancer with a hemostatic sealant: the CoStasis surgical hemostat. Gastrointest Endosc 2002;55:735-40.

30. Bhamidipati CM, Coselli JS, LeMaire SA. BioGlue in 2011: what is its role in cardiac surgery? J Extra Corpor Technol 2012;44:P6-12.

31. Florek HJ, Brunkwall J, Orend KH, et al. Results from a First-in-Human Trial of a Novel Vascular Sealant. Front Surg 2015;2:29.

32. Singer AJ, Quinn JV, Hollander JE. The cyanoacrylate topical skin adhesives. Am J Emerg Med 2008;26:490-6.

33. Granville-Chapman J, Jacobs N, Midwinter MJ. Prehospital haemostatic dressings: a systematic review. Injury 2011;42:447-59.

34. Li J, Cao W, Lv XX, et al. Zeolite-based hemostat QuikClot releases calcium into blood and promotes blood coagulation in vitro. Acta Pharmacol Sin 2013;34:367-72.

35. Li Y, Li H, Xiao L, et al. Hemostatic Efficiency and Wound Healing Properties of Natural Zeolite Granules in a Lethal Rabbit Model of Complex Groin Injury. Materials (Basel) 2012;5.

36. Yu L, Shang X, Chen H, et al. A tightly-bonded and flexible mesoporous zeolite-cotton hybrid hemostat. Nat Commun 2019;10:1932.

37. Williams LB, Haydel SE. Evaluation of the medicinal use of clay minerals as antibacterial agents. Int Geol Rev 2010;52:745-70.

38. Carraway JW, Kent D, Young K, et al. Comparison of a new mineral based hemostatic agent to a commercially available granular zeolite agent for hemostasis in a swine model of lethal extremity arterial hemorrhage. Resuscitation 2008;78:230-5.

39. Pérez-Gaxiola G, Cuello-García CA, Florez ID, et al. Smectite for acute infectious diarrhoea in children. Cochrane Database Syst Rev 2018;4:CD011526.

40. Kheirabadi BS, Scherer MR, Estep JS, et al. Determination of efficacy of new hemostatic dressings in a model of extremity arterial hemorrhage in swine. J Trauma 2009;67:450-9; discussion 459-60.

41. Allison HA. Hemorrhage Control: Lessons Learned From the Battlefield Use of Hemostatic Agents That Can Be Applied in a Hospital Setting. Crit Care Nurs Q 2019;42:165-72.

42. Johnson D, Bates S, Nukalo S, et al. The effects of 
QuikClot Combat Gauze on hemorrhage control in the presence of hemodilution and hypothermia. Ann Med Surg (Lond) 2014;3:21-5.

43. Rall JM, Cox JM, Songer AG, et al. Comparison of novel hemostatic dressings with QuikClot combat gauze in a standardized swine model of uncontrolled hemorrhage. J Trauma Acute Care Surg 2013;75:S150-6.

44. Kheirabadi BS, Terrazas IB, Williams JF, et al. Negativepressure wound therapy: a hemostatic adjunct for control of coagulopathic hemorrhage in large soft tissue wounds. J Trauma Acute Care Surg 2012;73:1188-94.

45. Abbott EM, Nandyala SV, Schwend RM. Does a kaolinimpregnated hemostatic dressing reduce intraoperative blood loss and blood transfusions in pediatric spinal deformity surgery? Spine (Phila Pa 1976) 2014;39:E1174-80.

46. Politi L, Aprile A, Paganelli C, et al. Randomized clinical trial on short-time compression with Kaolin-filled pad: a new strategy to avoid early bleeding and subacute radial artery occlusion after percutaneous coronary intervention. J Interv Cardiol 2011;24:65-72.

47. Available online: https://quikclot.com/QuikClot/Products. 2021.

48. Rao SB, Sharma CP. Use of chitosan as a biomaterial: studies on its safety and hemostatic potential. J Biomed Mater Res 1997;34:21-8.

49. Rondon EP, Benabdoun HA, Vallières F, et al. Evidence Supporting the Safety of Pegylated DiethylaminoethylChitosan Polymer as a Nanovector for Gene Therapy Applications. Int J Nanomedicine 2020;15:6183-200.

50. Chou TC, Fu E, Wu CJ, et al. Chitosan enhances platelet adhesion and aggregation. Biochem Biophys Res Commun 2003;302:480-3.

51. Huang Y, Feng L, Zhang Y, et al. Hemostasis mechanism and applications of $\mathrm{N}$-alkylated chitosan sponge. Polym Adv Technol 2017;28.

52. Hattori $H$, Ishihara $M$. Changes in blood aggregation with differences in molecular weight and degree of deacetylation of chitosan. Biomed Mater 2015;10:015014.

53. Khan MA, Mujahid M. A review on recent advances in chitosan based composite for hemostatic dressings. Int J Biol Macromol 2019;124:138-47.

54. Dowling MB, Kumar R, Keibler MA, et al. A selfassembling hydrophobically modified chitosan capable of reversible hemostatic action. Biomaterials 2011;32:3351-7.

55. Liu L, Lv Q, Zhang Q, et al. Preparation of Carboxymethyl Chitosan Microspheres and Their Application in Hemostasis. Disaster Med Public Health
Prep 2017;11:660-7.

56. Pan H, Fan D, Cao W, et al. Preparation and Characterization of Breathable Hemostatic Hydrogel Dressings and Determination of Their Effects on FullThickness Defects. Polymers (Basel) 2017;9:727.

57. Deineka V, Sulaieva O, Pernakov N, et al. Hemostatic performance and biocompatibility of chitosan-based agents in experimental parenchymal bleeding. Mater Sci Eng C Mater Biol Appl 2021;120:111740.

58. Zhong QK, Wu ZY, Qin YQ, et al. Preparation and Properties of Carboxymethyl Chitosan/Alginate/ Tranexamic Acid Composite Films. Membranes (Basel) 2019;9:11.

59. Ouyang Q, Hou T, Li C, et al. Construction of a composite sponge containing tilapia peptides and chitosan with improved hemostatic performance. Int J Biol Macromol 2019;139:719-29.

60. Sun X, Fang Y, Tang Z, et al. Mesoporous silica nanoparticles carried on chitosan microspheres for traumatic bleeding control. Int J Biol Macromol 2019;127:311-9.

61. Seon GM, Lee MH, Kwon BJ, et al. Recombinant batroxobin-coated nonwoven chitosan as hemostatic dressing for initial hemorrhage control. Int J Biol Macromol 2018;113:757-63.

62. Koumentakou I, Terzopoulou Z, Michopoulou A, et al. Chitosan dressings containing inorganic additives and levofloxacin as potential wound care products with enhanced hemostatic properties. Int J Biol Macromol 2020;162:693-703.

63. Tan SR, Tope WD. Effectiveness of microporous polysaccharide hemospheres for achieving hemostasis in mohs micrographic surgery. Dermatol Surg 2004;30:908-14.

64. Egeli T, Sevinç A, Bora S, et al. Microporous polysaccharide hemospheres and seroma formation after mastectomy and axillary dissection in rats. Balkan Med J 2012;29:179-83.

65. Suarez-Kelly LP, Pasley WH, Clayton EJ, et al. Effect of topical microporous polysaccharide hemospheres on the duration and amount of fluid drainage following mastectomy: a prospective randomized clinical trial. BMC Cancer 2019;19:99.

66. Hou Y, Xia Y, Pan Y, et al. Influences of mesoporous zinc-calcium silicate on water absorption, degradability, antibacterial efficacy, hemostatic performances and cell viability to microporous starch based hemostat. Mater Sci Eng C Mater Biol Appl 2017;76:340-9. 
67. Aydemir Sezer U, Sahin İ, Aru B, et al. Cytotoxicity, bactericidal and hemostatic evaluation of oxidized cellulose microparticles: Structure and oxidation degree approach. Carbohydr Polym 2019;219:87-94.

68. Available online: https://www.jnjmedicaldevices.com/enUS/product/surgicel-original-absorbable-hemostat. 2021.

69. Liu J, Hong $W, W u ~ W$, et al. Delayed Absorption of Oxidized Cellulose (Surgicel) in Post-Thyroidectomy Patients. J Ultrasound Med 2016;35:1349-51.

70. Piozzi GN, Reitano E, Panizzo V, et al. Practical Suggestions for Prevention of Complications Arising from Oxidized Cellulose Retention: A Case Report and Review of the Literature. Am J Case Rep 2018;19:812-9.

71. Udangawa RN, Mikael PE, Mancinelli C, et al. Novel Cellulose-Halloysite Hemostatic Nanocomposite Fibers with a Dramatic Reduction in Human Plasma Coagulation Time. ACS Appl Mater Interfaces 2019;11:15447-56.

72. Chan L, Jin Y, Heng P. Cross-linking mechanisms of calcium and zinc in production of alginate microspheres. Int J Pharm 2002;242:255-8.

73. Lee KY, Mooney DJ. Alginate: properties and biomedical applications. Prog Polym Sci 2012;37:106-26.

74. Pan M, Tang Z, Tu J, et al. Porous chitosan microspheres containing zinc ion for enhanced thrombosis and hemostasis. Mater Sci Eng C Mater Biol Appl 2018;85:27-36.

75. Davie EW, Kulman JD. An overview of the structure and function of thrombin. Semin Thromb Hemost 2006;32 Suppl 1:3-15.

76. Posma JJ, Posthuma JJ, Spronk HM. Coagulation and non-coagulation effects of thrombin. J Thromb Haemost 2016;14:1908-16.

77. Wolberg AS, Campbell RA. Thrombin generation, fibrin clot formation and hemostasis. Transfus Apher Sci 2008;38:15-23.

78. Chapman WC, Singla N, Genyk Y, et al. A phase 3, randomized, double-blind comparative study of the efficacy and safety of topical recombinant human thrombin and bovine thrombin in surgical hemostasis. J Am Coll Surg 2007;205:256-65.

79. Singla NK, Gasparis AP, Ballard JL, et al. Immunogenicity and safety of re-exposure to recombinant human thrombin in surgical hemostasis. J Am Coll Surg 2011;213:722-7.

80. Mandell SP, Gibran NS. Fibrin sealants: surgical hemostat, sealant and adhesive. Expert Opin Biol Ther 2014;14:821-30.

81. Fischer CP, Wood CG, Shen J, et al. A randomized trial of aprotinin-free fibrin sealant versus absorbable hemostat.
Clin Appl Thromb Hemost 2011;17:572-7.

82. Koea JB, Batiller J, Aguirre N, et al. A multicentre, prospective, randomized, controlled trial comparing EVARREST TM fibrin sealant patch to standard of care in controlling bleeding following elective hepatectomy: anatomic versus non-anatomic resection. HPB (Oxford) 2016;18:221-8.

83. Chetter I, Stansby G, Sarralde JA, et al. A Prospective, Randomized, Multicenter Clinical Trial on the Safety and Efficacy of a Ready-to-Use Fibrin Sealant as an Adjunct to Hemostasis during Vascular Surgery. Ann Vasc Surg 2017;45:127-37.

84. Moench C, Mihaljevic AL, Hermanutz V, et al. Randomized controlled multicenter trial on the effectiveness of the collagen hemostat Sangustop ${ }^{\circledR}$ compared with a carrier-bound fibrin sealant during liver resection (ESSCALIVER study, NCT00918619). Langenbecks Arch Surg 2014;399:725-33.

85. Verra WC, van Hilten JA, Honohan Á, et al. The effect of a fibrin sealant on knee function after total knee replacement surgery. Results from the FIRST trial. A multicenter randomized controlled trial. PLoS One 2018;13:e0200804.

86. Carlson MA, Calcaterra J, Johanning JM, et al. A totally recombinant human fibrin sealant. J Surg Res 2014;187:334-42.

87. Bochicchio GV, Gupta N, Porte RJ, et al. The FINISH-3 trial: a phase 3 , international, randomized, single-blind, controlled trial of topical fibrocaps in intraoperative surgical hemostasis. J Am Coll Surg 2015;220:70-81.

88. McDonald TO, Britton B, Brogmann AR, et al. Biocompatibility and bioabsorption of microfibrillar collagen hemostat in experimental animals. Toxicology 1977;7:37-44.

89. Lim YS, Ok YJ, Hwang SY, et al. Marine Collagen as A Promising Biomaterial for Biomedical Applications. Mar Drugs 2019;17:467.

90. Farndale RW, Sixma JJ, Barnes MJ, et al. The role of collagen in thrombosis and hemostasis. J Thromb Haemost 2004;2:561-73.

91. Slezak P, Monforte X, Ferguson J, et al. Properties of collagen-based hemostatic patch compared to oxidized cellulose-based patch. J Mater Sci Mater Med 2018;29:71.

92. Li H, Cheng W, Liu K, et al. Reinforced collagen with oxidized microcrystalline cellulose shows improved hemostatic effects. Carbohydr Polym 2017;165:30-8.

93. Cheng X, Shao Z, Li C, et al. Isolation, Characterization and Evaluation of Collagen from Jellyfish Rhopilema 
esculentum Kishinouye for Use in Hemostatic Applications. PLoS One 2017;12:e0169731.

94. Liening DA, Lundy L, Silberberg B, et al. A comparison of the biocompatibility of three absorbable hemostatic agents in the rat middle ear. Otolaryngol Head Neck Surg 1997;116:454-7.

95. Imani R, Rafienia M, Emami SH. Synthesis and characterization of glutaraldehyde-based crosslinked gelatin as a local hemostat sponge in surgery: an in vitro study. Biomed Mater Eng 2013;23:211-24.

96. Nakielski P, Pierini F. Blood interactions with nano- and microfibers: Recent advances, challenges and applications in nano- and microfibrous hemostatic agents. Acta Biomater 2019;84:63-76.

97. Chen S, Carlson MA, Zhang YS, et al. Fabrication of injectable and superelastic nanofiber rectangle matrices ("peanuts") and their potential applications in hemostasis. Biomaterials 2018;179:46-59.

98. Chao HH, Torchiana DF. BioGlue: albumin/ glutaraldehyde sealant in cardiac surgery. J Card Surg 2003;18:500-3.

99. Wang G, Liu N, Guo M. Use of Whey Protein as a Natural Polymer for Tissue Adhesive: Preliminary Formulation and Evaluation In Vitro. Polymers (Basel)

Cite this article as: Zhong Y, Hu H, Min N, Wei Y, Li X, Li X. Application and outlook of topical hemostatic materials: a narrative review. Ann Transl Med 2021;9(7):577. doi: 10.21037/atm-207160
2018;10:843.

100.Peng HT, Blostein MD, Shek PN. Experimental optimization of an in situ forming hydrogel for hemorrhage control. J Biomed Mater Res B Appl Biomater 2009;89:199-209.

101. Bu Y, Zhang L, Liu J, et al. Synthesis and Properties of Hemostatic and Bacteria-Responsive in Situ Hydrogels for Emergency Treatment in Critical Situations. ACS Appl Mater Interfaces 2016;8:12674-83.

102.Sohn JJ, Gruber TM, Zahorsky-Reeves JL, et al. Comparison of 2-Ethyl-Cyanoacrylate and 2-ButylCyanoacrylate for Use on the Calvaria of CD1 Mice. J Am Assoc Lab Anim Sci 2016;5 5:199-203.

103. Gulalp B, Seyhan T, Gursoy S, et al. Emergency wounds treated with cyanoacrylate and long-term results in pediatrics: a series of cases; what are the advantages and boards? BMC Res Notes 2009;2:132.

104. Malhotra V, Dayashankara Rao JK, Arya V, et al. Evaluating the use of octyl-2-cyanoacrylate in unilateral cleft lip repair. Natl J Maxillofac Surg 2016;7:153-8.

105. Borie E, Rosas E, Kuramochi G, et al. Oral Applications of Cyanoacrylate Adhesives: A Literature Review. Biomed Res Int 2019;2019:8217602. 